Western Washington University

Western CEDAR

\title{
Torn Lace and Other Transformations: Rewriting the Bride's Script in Selected Stories by Emilia Pardo Bazán
}

Joan M. Hoffman

Western Washington University, joan.hoffman@wwu.edu

Follow this and additional works at: https://cedar.wwu.edu/mcl_facpubs

Part of the Modern Languages Commons, and the Spanish Literature Commons

\section{Recommended Citation}

Hoffman, Joan M., "Torn Lace and Other Transformations: Rewriting the Bride's Script in Selected Stories by Emilia Pardo Bazán" (1999). Modern \& Classical Languages. 4.

https://cedar.wwu.edu/mcl_facpubs/4 


\title{
Torn Lace and Other Transformations: Rewriting the Bride's Script in Selected Stories by Emilia Pardo Bazán
}

\author{
Joan M. Hoffman \\ Western Washington University \\ ...dejar a la novia que se riese, que se alegrase; \\ ¡estaba aún en la antesala del grave deber! \\ -Emilia Pardo Bazán ("La boda")
}

\begin{abstract}
In three of her tales_-El encaje roto" (1897), “Champagne” (1898), and "La boda” (1909), Pardo Bazán presents her readers with a bride on her wedding day; in each case, and each in her own way, the bride breaks with convention and time-honored tradition on this most anticipated day of her life, only to see her life irrevocably altered - not by the marriage-but by her own actions and decisions. The juxtaposition of these three tales with a fourth later one, "La punta del cigarro" (1914), the story of a man in search of a wife wherein a male narrator delineates nineteenth-century society's requirements for the ideal wife, illustrates Doña Emilia's astute subversion of the traditional feminine ideal and her empowerment of female protagonists.
\end{abstract}

Key Words: Pardo Bazán (Emilia), Spanish literature, short story, women's writing, marriage, feminine (domestic) ideal, Angel in the House (Angel del hogar), subversion

A s evidenced in the above epigraph, the wedding ceremony is nothing less than a defining moment, a true threshold, in the life of the young nineteenth-century novia. Marking that crucial transition from being the father's daughter to the husband's wife, the wedding-complete with its months of minute preparations, its sumptuous fabrics and delectable banquets, and its promises of future prosperity-is meant to be a proud and public validation of the prevailing bourgeois social order, the model domestic circumstancethe domestic ideal-complete with "todas las garantías de la felicidad" (Pardo Bazán, CC 1: 332). ${ }^{1}$ On this one most revered and anticipated day, the bride, queen for a time, is ushered down the aisle right into what is meant to be a quiet lifetime as a wife and domestic partner, her long-awaited "happily-ever-after."

Having vowed to love, honor, and obey, the new bride is conscripted into upholding that domestic ideal whose very foundation is marriage; indeed, Tony Tanner asserts that marriage is nothing less than the "structure that maintains the Structure" of middle-class society (15). As a partner in this marital enterprise, then, the happy bride can rest assured in the knowledge that she is playing a crucial societal role. In great part, thanks to her, all is right with the world.

The happy scene has its dark side, however, as Carolyn Heilbrun so well articulates in her thought-provoking analysis of Penelope:

In literature and out, through all recorded history, women have lived by a script they did not write. Their destiny was to be married, circulated; to be given by one man, the father, to another, the husband; to become the mothers of men." (108)

Women are mere actors in a myth written for them and not $b y$ them. ${ }^{2}$ Rachel DuPlessis concurs, arguing that women are "not themselves in control of the processes by which they are defined" and, further, that they are "muted" (41). Her definition of this term is particularly useful for this study: "the sound different, tampered down, repressed, but still speaking, with the speech bearing the marks of partial silencing." Accordingly, despite her crucial role as a guardian of the 
marital institution, after those patriarchally conceived vows are spoken, the nineteenthcentury wife has little power or freedom, little voice, within her own marriage. ${ }^{3}$ This dark side is not lost on Pardo Bazán. Being a wife, the epigraph reminds us, is a young lady's grave deber meant to be somberly undertaken with the utmost solemnity. The bride's joy must remain at the wedding banquet and her laughter must be silenced as such passions seemingly will find no quarter in her "happily-ever-after." The pessimistic irony inherent in this characterization of marriage is, to say the least, intriguing, and can not be dismissed. Indeed, many critics before myself-Janet Pérez, Joyce Tolliver, and Thomas Feeny among them-have noted that this tone is much a part of what Doña Emilia often tries to accomplish with her fiction. As Pérez points out, "Pardo Bazán repeatedly subvert[s] 'romantic' idealization of courtship, engagement, and marriage" ("Winners" 355). ${ }^{4}$

Emilia Pardo Bazán does not, however, engage in pessimism for pessimism's sake. Her tireless efforts to broaden the feminist debate in Spain are well documented by Geraldine Scanlon, Ruth El Saffar and others. Her literary output-fiction and nonfiction alike-is replete with progressive views on women's rights, abilities, and responsibilities; and she ceaselessly decries the lack of self-determination for women, as here in a passage from "Una opinión sobre la mujer" that curiously portends Heilbrun's words:

El error fundamental que vicia el criterio común respecto de la criatura del sexo femenino...es el de atribuirle un destino de mera relación; de no considerarla en sí, ni por sí, ni para sí, sino en los otros, por los otros y para los otros. (158)

Clearly, throughout her writing, Pardo Bazán engages in a veritable dialogue with her generation, a dialogue in search of "the untold story," the other side of [the] wellknown tale... of women's existence" (DuPlessis 3). Pardo Bazán demands that women be permitted to let their own voices be heard, to live by a script of their own making.
As one of the few viable options for the nineteenth-century woman, marriage is a keynote in Pardo Bazán's dialogue, a prime target for script-revision. As Maryellen Bieder points out, the aim of even Doña Emilia's first published story, "Un matrimonio del siglo XIX" (1866), is "to reposition the reader in regard to marriage" $(155 \mathrm{n} 9) .^{5}$ This is a script that this author is constantly rewriting, subverting, and undermining, in order to explore expanded alternatives for women, to give women a voice, a choice, in their own destiny.

To this end, Pardo Bazán demonstrates that the "happily-ever-after" is not always so, and that a woman can survive, even thrive, both inside and outside of marriage-as long as she is afforded some autonomy over the process, some voice in her own destiny. Pardo Bazán's fiction is abundant with brides, from Luisa in the early "Un matrimonio del siglo XIX" to Nucha in the masterpiece, Los pasos de Ulloa (1886) and beyond. This study, however, will focus on the brides in three later, particularly innovative short stories-"El encaje roto" (1897), "Champagne" (1898), and "La boda" (1909). ${ }^{6}$

The shared focal point of these stories is a wedding day, that long-awaited, life-altering antesala; but not one of these protagonist-brides enters passively through that threshold into marriage. In each case she breaks with societal convention and timehonored tradition only to see her life irrevocably transformed-not by the marriage-but by her own astonishing actions and decisions. All three of these memorable women exercise a startling and unexpected self-determination; and in so doing, propose three distinct alternatives to the "happilyever-after," the model nineteenth-century bourgeois marriage.

To better appreciate the revolutionary nature of the brides' decisions in these three stories, I find it helpful to examine a fourth, later story, "La punta del cigarro" (1914). This is the clever tale of a man in search of a wife, wherein a rather unsavory male protagonist, Cristóbal Morón, casts himself as a sort of arbiter elegantiae in de- 
lineating his—and society's-requirements for the perfect marital partner. Morón, then, becomes Doña Emilia's mouthpiece, clearly articulating the traditional patriarchally determined expectations for women of this period. This is precisely the male-authored script that Pardo Bazán repeatedly subverts, the myth that she transforms, throughout her career and specifically in the stories to be examined here.

The author's subversive process begins early in this story as, from the first, Cristóbal Morón is portrayed as a disagreeable fellow coldly going about the business of finding the model wife. From the first line he is portrayed as indifferent, unemotional; he is "resuelto a contraer matrimonio, porque es una de esas cosas que nadie deja de hacer, tarde o temprano" (3: 398). He remains wholly uninspired by such emotions as love for any particular woman or even by some nebulous appreciation or esteem for women in general. He is influenced, instead, by the more base belief that women in search of husbands regularly engage in deception: "No ignoraba cuánto disimulan, generalmente, su verdadera indole las muchachas casaderas" (3: 398). This protagonist, therefore, finds himself obliged to answer trickery with trickery and devises a rather perverted marriage test for any prospective wife, consisting of the carefully orchestrated application of a cigarette butt to a pretty gown. The candidate's reaction to this unfortunate "accident" will expose her true character and thus determine her marriageability. Viewed in the light of his offensive personality and his perverse experiment, Morón's —and, lest we forget, society's-inventory of specifications for the exemplary companion seems unjust, all but unattainable, and ripe for subversion by a willing and able author:

En primer término, deseaba Cristóbal que la que hubiese de conducir al ara consabida tuviese un genio excelente; que su humor fuese igual y tranquilo y más bien jovial, superior a esos incidentes cotidianos que causan irritaciones y cóleras, pasajeras, sí, pero que, repetidas, no dejan de agriar la existencia común. Una cara siempre sonriente, una complacencia continua, eran el ideal femenino de Cristóbal. (3: 398)
In response to this almost interminable list of expectations, Pardo Bazán creates the character of Sarito Vilomara, a "chiquilla," cheerful and wholly unruffled by Morón's scrutiny, who emerges as his feminine ideal incarnate, his embodiment of "la aquiescencia más completa"; it is she, he believes, who will remain "siempre dispuesta a cuanto él quisiese sugerir" (3: 399). Sarito is to fill the coveted position as the "ángel anhelado para cobijar bajo sus alas un corazón de soltero"; she has fulfilled the requirements and is to be the wife of Cristóbal Morón (3: 399).

It is no coincidence that Morón's feminine ideal should possess such qualities as submission, compliance, reticence, and a perpetually happy disposition; neither is it coincidence that she be designated as nothing less than an angel. For Morón's viewsnot to be dismissed as mere literature-are entirely reflective of those of his flesh-andbone Victorian contemporaries. As shown by such critics as Bridget Aldaraca, Alicia Andreu, Susan Kirkpatrick, and Catherine Jagoe, the image of the Angel in the House, as taken from Coventry Patmore's epic British poem of the same name $(1854,1856)$, was also a well-known figure in nineteenthcentury Spanish society. In fact, Kirkpatrick documents the existence of the angel-figure in Spain as early as the 1840 s, concluding that "the influence of the stereotype only intensified after 1850" (282).

Indeed, this angelic ideal of femininity was popularized in Spain by María del Pilar Sinués de Marco's conduct manual for young wives entitled El ángel del hogar, first published in 1859 and then in numerous editions into the twentieth century. Thus, generations of Spanish brides were counseled to cultivate those qualities that the likes of Morón demanded of their partners, with the result being a "gentle and frail woman composed not of flesh and blood but of sweetness and light" (Aldaraca, "Cult" 76). Nevertheless, as Morón's predicament at the end of the tale proves, "La punta del cigarro" is in no way meant to champion the Victorian patriarchal ideal of the ángel del hogar. In an inventive turnabout, this tradi- 
tional script is revised; Sarito is not what Morón believed her to be nor what society expects her to be. It is not the wife but instead the husband, now proven to be as absurd as the vaudeville performance he attends, who is here subdued, silenced by the astonishing transformation of Sarito from that earlier submissive angel into a veritable "víbora" after just weeks of marriage (3: 400).

As is the case with Sarito, so too do the other brides-to-be examined here break free from the angel mold to gain a voice for self-determination; but such defiance is not without some cost in a society that offers few acceptable options to its women. Pardo Bazán's juxtaposition, here, of unconventional, outspoken novias pitted against established expectations, the ángel del hogar, and the grave deber, constitutes the author's attack upon the prevailing myth of the feminine ideal; at the same time, it highlights the sometimes ambiguous and often difficult situation in which each of these not-so-traditional brides finds herself as the sun sets on her wedding day and she grapples to redefine her own happily-ever-after.?

As the scandalized narrator of "El encaje roto" reports, Micaelita Aránguiz's wedding day, splendid to the last detail, becomes nothing less than "un terrible drama," a "momento fatal" (1:332), due to the bride's astonishing but adamant refusal-with "un 'no' claro y enérgico"- to marry the very eligible Bernardo de Meneses (1:331). This "no," "seco como un disparo" signaled Micaelita's enigmatic rejection, at a very inconvenient moment and with no explanation, of a man she professed to liking, whom she perhaps even loved (1:332). More strikingly, however, this was a open rejection of the substantial material advantages of such a match, advantages much discussed among the gossips in attendance at the memorable event. With this one tiny but powerful word, Micaelita was capriciously relinquishing everything from the beautiful heirloom wedding gown to a "magnifica herencia" that would have easily secured her future (1: 331).

The narrator's pounding repetition of the bride's negative response, coupled with the gossipy tone of the piece, emphasizes the shock and disbelief of such a scene, only exacerbated by Micaelita's social class:

No son inauditos los casos, y solemos leerlos en los periódicos; pero ocurren entre gente de clase humilde, de muy modesto estado, en esferas donde las conveniencias sociales no embarazan la manifestación franca y espontánea del sentimiento y de la voluntad. (1: 331)

Evidently, Micaelita and women of her position were expected to surrender personal authenticity and autonomy to more powerful societal interests. This bride has already provoked a scandal by stopping the wedding; and she can not find it in herself to justify her actions: "Micaelita se limitaba a decir que había cambiado de opinión" (1: 332). Candor is a luxury that the bourgeois angel-woman can ill afford.

Those same society gossips who attended Micaelita's aborted wedding, who were appalled at her response, and who were left wondering why she so carelessly risked so much, would also contend that she paid dearly for her impulsive act; Emilia Pardo Bazán offers an alternate reading. When next the narrator encounters the would-be-bride she is sunning herself at a fashionable spa. Not only does this detail calm any doubts about Micaelita's happiness or her economic situation, but more importantly, as we are reminded, "no hay cosa que facilite las relaciones como la vida de balneario" (1:332). That is, in these freer surroundings, outside of marriage, and in the company of women-her mother and the narrator-Micaelita finally explains her memorable decision; she finds her own voice and finally enjoys the luxury of frankness.

Micaelita openly decries the restrictions placed upon the novia of her social class: "Maldecía yo mil veces la sujeción de la mujer soltera, para la cual es imposible seguir los pasos a su novio, ahondar en la realidad y obtener informes leales, sinceros hasta la crudeza" (1: 332-33); she now discloses that not until her wedding day did she ascertain her groom's true character: 
"se alzó un telón y detrás apareció desnuda un alma" (1: 333). In a split second, with one small tear in the cherished wedding dress followed by the slightest alteration of facial expression, she alone realized that Bernardo had a strong but easy tendency toward violence, that he valued possessions over people, and that she did not want to spend her days as his wife.

Micaelita, it seems, instinctively understood the risk she was taking at the very moment of doing so. She knew that she could expect no sympathy from her wedding guests. She would not be taken seriously, having made such an impetuous, lifealtering decision based upon what could be perceived as a harmless facial tic. In the end, however, Micaelita concludes that a violent character is not harmless and that explanations do not matter. Far from surrendering to tradition, by uttering one small but powerful word and walking away from a potentially abusive marriage, Micaelita rejects the angel-image and the grave deber outright; she opts instead for safety, authenticity, and self-determination.

Although the unnamed prostitute in "Champagne" appears to be the complete antithesis of the bourgeois bride, Micaelita Aránguiz, in fact the two have much in common. Just as Micaelita is supposed to dissemble her candor out of deference to her social position, so too is the "compañera momentánea" expected to conceal her sadness, precisely because of hers (1:293). Just as the narrator of Micaelita's tale is stunned at her openness, so too is the prostitute's curious client who is prompted by her unhappy demeanor to wonder "por qué una hembra que hacía profesión de jovialidad se permitía mostrar sentimientos tristes, lujo reservado solamente a las mujeres honradas" (1:293). Further, the prostitute, like Micaelita, experiences a disastrous wedding day and finds a voice with which to discuss it only after the fact, in a freer environment outside of marriage.

Far from being her refuge from an unloving stepmother, marriage is forced upon this protagonist against her will in order to be rid of her-_ja casarse!, no vale replicar"
(1: 294). It comes as a startling revelation to the reader-or perhaps not-that this type of compelled matrimony is common practice at this time. As the prostitute's unruffled client calmly reports, "Hija, por ahora no encuentro mucho de particular en tu historia. Casarse así rabiando y por máquina, es bastante frecuente" (I: 294). The juxtaposition of the client's cool demeanor and his harsh words serve as a strong condemnation of the marital institution.

Pardo Bazán, however, does not suspend her attack here; irony is another mighty weapon in her literary arsenal. Ironically then, despite the many qualities of the groom-"acomodado, caurentón, formal, recomendable, seriote" (1: 294) - this match is the reluctant bride's undoing: "Por haberme casado, ando como me ves" (1: 293), because she dares to challenge-unwittingly and on the very day of her wedding-the tradition being imposed upon her. In sharp contrast to the expected meek and submissive bride, this protagonist proceeds to get drunk at her own wedding reception: "de puro borrachita, ¿sabes?..., de nada me enteré" (1: 295). Instead of dutifully silencing her sorrow at the loss of her true love, she drowns it in champagne and then, shockingly, proclaims it to her new husband. As she recounts:

se me desató la lengua, se me arrebató la sangre, y le solté de pe a pa lo del teniente, y que sólo al teniente quería, y teniente va y teniente viene, y dale con que si me han casado contra mi gusto, y toma con que ya me desquitaría y le mataría a palos.... (1: 294)

Without the protection and security of marriage and with no other options, now she chooses not to return to her parents and not to petition support from her husband-both fates she deems worse, ironically again, than the one that eventually befalls her. At least prostitution is a profession without secrets where she discovers freedoms unknown to middle-class brides. Foremost among these is the ability to speak the truth, her truth. It is not by mere chance, in fact, that there is little narrative mediation in this tale; Pardo Bazán confers the power and the authority of voice to her character, granting 
her the freedom to tell her own story in her own words.

Nonetheless, both character and author well recognize the inherent danger of such liberty; it comes only at great expense. The protagonist is, after all, a prostitute, who accurately laments: "creo si todas las mujeres hablasen lo que piensan, como hice yo por culpa del champagne, más de cuatro y más de ocho se verían peor que esta individua" (1:295); and Pardo Bazán elected not to publish "Champagne" in any of the popular journals of her day, where her other stories could be found. Providing a public forum to a prostitute to expound on the sacrosanct topic of marriage seemed even too scandalous for Doña Emilia. The astute observation, by both character and author, that the angel-woman must surrender her status, her honor, even her happiness if she is to have a voice and a thought of her own is not only a sad truth, but a powerful indictment of the system that perpetuates nothing less than compliant hypocrisy in its women.

In contrast to the unnamed prostitute and to Micaelita Aránguiz who find it necessary-at immense social cost— to escape this stifling system to acquire a voice and a measure of independence, Regina in " $\mathrm{La}$ boda" consciously chooses to work within the system to determine her own future autonomously. She, in fact, demonstrates a propensity for self-determination from the outset. With the example of a strong female role-model in her mother, a school director, Regina was drawn away from the sort of abnegation endured by the likes of Micaelita and the prostitute. Instead, her mind was opened, her horizons broadened beyond her nineteenth-century reality, as expressed by the narrator's description of her: "Regina era una rubia airosa, aseñoritada como pocas, instruidita, soñadora por naturaleza y también por haber leído bastante historia, novelas, versos, cosas de amores" (3: 109). Unquestionably, Regina views marriage not as the mere means to economic and social stability and furtherance of the species. For her, nurtured by her romantic musings, it must be more than a cold contract, more than a grave deber. Marriage must be nothing less than a love match.

This attitude drives Regina to her rebellion-against the husband of her mother's choosing. True, Don Elías, is a successful, older, businessman who could offer her economic stability and social standing. Nonetheless, with a determination unknown heretofore, Regina refuses him outright and in a strong voice. As the narrator reports, "Regina luchó años enteros antes de aceptarle. No daba razones. No quería. Que no le hablasen de semejante cosa. Era dueña de su voluntad: no tenía ambición, no estaba en venta..." (3: 109).

This striking autonomy, in sharp contrast to the other novias here, is prompted simply by the fact that Elías is not Damián, the dashing French teacher for whom Regina harbors an unrequited love, longsuffered in silence as the object of her desire completely ignores her in pursuit of a more lucrative match. Only once, thoroughly convinced of the hopelessness of her unanswered love-romantically described as a "paloma de blancas alas, rotas y sangrientas"-does Regina consent to be married to Don Elías (3: 110). ${ }^{8}$

Just as Regina showed herself to be in control of her own fate before her wedding, so does this same self-assurance continue on the day of the ceremony. Unscathed by bad timing, the new bride revels in the power she finally holds over Damián, who at last notices her in all of the finery of her wedding gown as she discerns, "trémula de placer," that "hoy le gusto" (3:110). So too does she show herself to be in command of the situation as she finally and conclusively chooses her own husband-at this late hour-over Damián, who-as it turns outknew all along of her feelings and did nothing. In a clever subversion, just as she has been manipulated, so does she manipulate-now taking her rightful place next to her groom, speaking tenderly for the first time to this man she does not love. In a calm voice, mirroring the expectations of all in attendance, Regina utters one simple sentence-"Mira que quiero sentarme a tu 
lado, ¿eh?” (3: 111); with that, she knowingly chooses power over passion. The crucial point is, however, that this is Regina's choice, not her mother's, not her husband's, not Damián's.

Moreover, Regina comes to this life-altering decision while arousing no suspicions among her wedding guests. The reader is reminded that "estuvo tierna, insinuante, $y$ el novio loco de alegría” (3: 111)—entirely expected behavior at a wedding reception. Unlike her sister novias, her break with social convention is more private than public; the joyous day ends without an embarrassing scene. Further, whereas being female in this society is a decided liability for Micaelita and the prostitute, Regina uses her femininity to her advantage, charming two men in order to orchestrate her own future.

Regina, like Micaelita and the prostitute before her, is charting new territory in the battle for self-determination against the male-authored myth that is meant to be her life; and as any soldier knows, the front line is a risky position. Revolutionary endeavors are generally hard-won and often ambiguous. In this society steeped in angel-mythology, women follow their hearts only at some peril. After all, Regina does choose to spend her life with a man she does not love; Micaelita pays a great social price for making exactly the opposite decision; and the prostitute is forced to sell her affections. Pardo Bazán, however, crafts her tales and subverts the myth in such a way that even would-be renegades, outcasts, and pariahs are viewed as ordinary women-who have made extraordinary yet utterly necessary decisions.

A $\mathrm{s}$ a result, the reader is left to conclude that Regina will find consolation in the quiet command she has over her husband in their private life together. Likewise, Micaelita will be remembered in the supportive company of women. Even the prostitute has no secrets and a certain liberty of which others may only dream. Certainly, as Pérez contends, "Pardo Bazán did not look upon matrimony as woman's only viable option" ("Winners"
355). To use Heilbrun's words from "What Was Penelope Unweaving," "we can only transform old tales, and recognize how women have transformed old tales in the past" (109). The lesson of these three women is precisely the lesson offered by Penelope; like that of their ancient sister, theirs "is a new story, the story of a woman's choice" (111). By facing down the old myth and writing her own script, each of these women has succeeded in transforming the old tale, and along with it, her own life. Each, in her own way, has demanded a measure of autonomy and come to terms with the grave deber, precisely by not surrendering to it.

\section{口 NOTES}

'Both "El encaje roto" (1: 331-33) and "La boda" (3: 109-11) convey especially well the importance of and the frenzied celebration that is the nineteenthcentury bourgeois wedding. All references to Pardo Bazán's short stories are taken from this collection of Cuentos completos, citing the story title, volume, and page numbers where appropriate.

'I borrow Heilbrun's definition here of "'myth' in the sense of the sustaining narratives of an ideology" (109).

${ }^{3}$ DuPlessis continues by noting that "giving voice to the voiceless" is one of the "prime maneuvers in feminist poetics" (41).

${ }^{4}$ I would say that Pérez's suggestion that Pardo Bazán "did not unreservedly subscribe to the prevailing domestic ideology" is an understatement. Pérez's own examples_-"the numerous instances of infidelity, domestic violence, spousal murders, abuse or neglect of women and children, emotional isolation and alienation of wives, and otherwise unhappy marriages in [Doña Emilia's] fiction"-confirm that the critic's assessment could be worded much more strongly ("Subversion" 35).

${ }^{5}$ In this early story Pardo Bazán is interested not so much in the woman's particular situation within marriage as with the broader issue of society's expectations of marriage as an institution.

${ }^{6}$ Pardo Bazán published short stories for an astonishing 55 years-from 1866 until her death in 1921. Bieder correctly notes that the author's most productive middle years, 1893-1910, are also her most inventive $(154 \mathrm{n} 4)$.

${ }^{7}$ As opposed to "El encaje roto," "Champagne," and "La boda," "La punta del cigarro" does nothing to explore any sort of difficulty or personal struggle that would account for Sarito's change in character. Moreover, little explanation is offered beyond, "La mujer es dulce y cariñosa cuando ama" (3: 401). For this 
reason, while the later tale is important for its articulation of the traditional feminine ideal, I find it less sophisticated or innovative than some of the stories from Pardo Bazán's earlier, most productive period.

${ }^{8}$ Contrast Regina's obvious struggle here to accept the feminine ideal with the complete lack of any such conflict on the part of Sarito in "La punta del cigarro," as mentioned above.

\section{- WORKS CITED}

Aldaraca, Bridget A. "El ángel del hogar: The Cult of Domesticity in Nineteenth-Century Spain." Theory and Practice of Feminist Literary Criticism. Ed. Gabriela Mora and Karen Van Hooft. Ypsilanti, MI: Bilingual, 1982. 62-87.

-. El ángel del hogar: Galdós and the Ideology of Domesticity in Spain. North Carolina Studies in the Romance Languages and Literatures 239. Chapel Hill, NC: U of North Carolina P, 1991.

Andreu, Alicia. Galdós y la literatura popular. Madrid: SGEL, 1982.

Bieder, Maryellen. "Plotting Gender/Replotting the Reader: Strategies of Subversion in Stories By Emilia Pardo Bazán.” Indiana Journal of Hispanic Literatures 2.1 (1993): 138-55.

Blanco, Alda. "The Moral Imperative for Women Writers." Indiana Journal of Hispanic Literatures 2.1 (1993): 91-110.

DuPlessis, Rachel Blau. Writing Beyond the Ending: Narrative Strategies of Twentieth-Century Women Writers. Bloomington: Indiana UP, 1985.

El Saffar, Ruth. "Emilia Pardo Bazán.” Spanish Women Writers: A Bio-Bibliographical Source Book. Eds. Linda Gould Levine, Ellen Engelson Marson, and
Gloria Feiman Waldman. Westport, CT: Greenwood, 1993. 378-88.

Feeny, Thomas. "Pardo Bazán's Pessimistic View of Love as Revealed in Cuentos de amor." Hispanófila 64 (1978): 7-14.

Heilbrun, Carolyn G. "What was Penelope Unweaving?” Hamlet's Mother and Other Women. New York: Columbia UP, 1990: 103-11.

Jagoe, Catherine. "The Subversive Angel in Fortunata y Jacinta." Anales Galdosianos 24 (1989): 79-91.

Kirkpatrick, Susan. Las Románticas: Women Writers and Subjectivitity in Spain 1835-1850. Berkely: U. of California P., 1989.

Pardo Bazán, Emilia. Cuentos completos. Ed. Juan Paredes Núñez. La Coruña: Fundación Pedro Barrie de la Maza, Conde de Fenosa, 1990. 4 vols.

—. "Una opinión sobre la mujer." "La mujer española" y otros artículos feministas. Ed. Leda Schiavo. Madrid: Nacional, 1976. 155-62.

Pérez, Janet. "Subversion of Victorian Values and Idea Types: Pardo Bazán and the 'Angel del hogar.” Hispanófila 113 (1995): 31-44.

—. "Winners, Losers and Casualties in Pardo Bazán's Battle of the Sexes." Letras Peninsulares 5.3 (1992): 347-56.

Scanlon, Geraldine M. “Gender and Journalism: Pardo Bazán's Nuevo Teatro Crítico. Culture and Gender in Nineteenth-Century Spain. Ed. Lou CharnonDeutsch and Jo Labanyi. Oxford: Clarendon, 1995. 230-49.

Tanner, Tony. Adultery in the Novel: Contract and Transgression. Baltimore: Johns Hopkins UP, 1979.

Tolliver, Joyce, ed. and introd. "El encaje roto" y otros cuentos. By Emilia Pardo Bazán. MLA Texts and Translations 5. New York: MLA, 1996. 